\title{
ACETYLCHOLINESTERASE AND $\alpha$-AMYLASE INHIBITORS FROM Mouriri elliptica MARTIUS LEAF EXTRACT
}

\author{
INIBIDORES DE ACETILCOLINESTERASE E $\alpha$-AMILASE A PARTIR DE \\ EXTRATOS FOLIARES DE Mouriri elliptica MARTIUS
}

\author{
Letícia Siqueira da SILVA ${ }^{1}$; Cinthia Alves PORFIRO ${ }^{1}$; Fabiano Guimarães SILVA ${ }^{1}$; \\ Agna Rita dos Santos RODRIGUES ${ }^{1}$; Paulo Sérgio PEREIRA ${ }^{1}$ \\ 1. Instituto Federal de Educação, Ciência e Tecnologia Goiano, Campus Rio Verde, Rio Verde, GO, Brasil. \\ paulo.pereira@ifgoiano.edu.br
}

\begin{abstract}
Population growth has raised food production, and new sources are needed to increase quantity and quality of agricultural products. Carbamates and organophosphates are insecticide classes used worldwide as acetylcholinesterase (AChE) inhibitors. Plants have a natural resistance to insects, which can be employed in pest control as a new alternative to reduce the use of chemicals. An alternative may be the use of $\alpha$-amylase inhibitors, which are digestive enzymes that impair pest species growth and development. Another would be acetylcholinesterase inhibitors since they damage the normal functioning of the central and peripheral nervous system, by releasing high concentrations of acetylcholine in cholinergic synapses. This substance accumulation increases stimulations that lead to behavioral changes, asphyxia, hyperactivity, and death. Botanical agrochemicals are believed to have advantages over synthetic ones, as they are rapidly degraded in the environment. In this scenario, plants have played an important role in pest control as sources of interest for the synthesis of new molecules for agricultural use. The present study evaluated acetylcholinesterase and $\alpha$ amylase inhibition by microplate method, from leaf extracts of Mouriri elliptica Martius with different polarities.
\end{abstract}

KEYWORDS: Cerrado. Enzymatic inhibition. Botanical pesticides. Chromatography.

\section{INTRODUCTION}

The food industry, agriculturists, public health, and environmental organizations have major concerns about crop protection in view of the damage pests may cause. There is a variety of more than 1025 pest insects and others arthropodes, among which beetles, moths, and mites stand out. Such an impact would cost about US\$ 17.7 billion per year, what surely affects world economy (LAMBRAÑO et al., 2015).

Although chemical insecticides are the main alternative to pest control, some efforts have been made to introduce sustainable measures, such as plant-based insecticides, which have proven to be more effective and safe for the ecosystem (KHALIQ et al., 2014).

A few classes of plant metabolites have already been applied to combat plagues, such as nicotine alkaloid found in Solanaceae family, and strychnine from Strychnos spp. In the North American market, azadirachtin terpenoids have been deployed as botanical pesticides (MIRESMAILLI; ISMAN, 2014).

Plants have a natural resistance to insects and diseases, such resistance mechanism can be employed in pest control as a new alternative to reduce chemical use. One alternative could be the inhibition of $\alpha$-amylase, which is a digestive enzyme; such inhibition impairs pest species growth and development (MEHRABADI, et al., 2012). Additionally, the use of acetylcholinesterase inhibitors is able to damage the normal functioning of the central nervous system by releasing high concentrations of acetylcholine in cholinergic synapses; this mechanism is also found in organophosphates, which affect insects and mammals (LARSEN, et al., 2016).

Among the plants used for the abovementioned purposes, Mouriri elliptica, a species belonging to the Melastomataceae family and native of the Cerrado (savannah-like vegetation), has been cited in a few scientific reports in the literature. These studies have demonstrated a rich fraction of terpenes in this plant species (ANDREO, 2008). In addition, some terpenes have repellent activities influencing on living organisms such as insects (KNAAK; FIUZA, 2010).

This study was undertaken to evaluate the inhibition of acetylcholinesterase and $\alpha$-amylase activities using M. elliptica leaf extracts. 


\section{MATERIAL AND METHODS}

\section{Botanical material and extract preparation}

Leaves from $M$. elliptica Martius, a native plant from the Cerrado biome, were collected in Planalto Verde, a city in Goiás state (Brazil). The plants were identified using the herbarium from the IF-Goiano, Campus in Rio Verde. Extracts were prepared using 1,000 g M. elliptica leaves, which were oven-dried at $40{ }^{\circ} \mathrm{C}$ and ground in a mill. The milled material was extracted by maceration for 24 hours, three times with $1000 \mathrm{~mL}$ ethyl acetate (EtOAc) and then three times with $100 \mathrm{~mL}$ methanol. The solutions were filtered and concentrated on a rotary evaporator. Next, the extracts were transferred to tared glasses and left in a hood until constant weight. Afterwards, they were lyophilized and stored in a refrigerator until biological assays.

\section{Methanol extract purification}

An aliquot of $10 \mathrm{~g}$ methanol extract was dissolved in $20-\mathrm{mL}$ water and then transferred to a separatory funnel where $20-\mathrm{mL}$ ethyl acetate was added. These samples were stirred until phase separation. The ethyl acetate layer was collected in a separate flask, and the aqueous layer was returned to the separatory funnel, being included a further 20 $\mathrm{mL}$ of ethyl acetate, a procedure repeated three times. The sample was placed in the hood for ethyl acetate evaporation and distributed $10 \mathrm{~mL}$ into two Falcon tubes.

About $20 \mathrm{~g}$ methanol extract was solubilized in 20 $\mathrm{mL}$ water and then centrifuged. The supernatant $(10$ $\mathrm{mL}$ ) was loaded onto a chromatographic column (45 $\mathrm{cm} \times 5.5 \mathrm{~cm}$ ) and packed with Sephadex LH-20, using water as mobile phase. In this column, the material depletion could be estimated after fifteen $100 \mathrm{~mL}$ vials.

\section{Ethyl acetate extract purification}

An aliquot of $10 \mathrm{~g}$ ethyl acetate extract was solubilized in $20 \mathrm{~mL}$ methanol, in a water bath, then centrifuged at $1000 \mathrm{rpm}$. A supernatant portion (10 $\mathrm{mL})$ was removed and applied to the chromatography column $(45 \mathrm{~cm} \times 5.5 \mathrm{~cm})$, being packed with Sephadex LH-20. In this column, the material depletion could be estimated after thirty $100-\mathrm{mL}$ vials, using methanol as mobile phase.

\section{Chemical profile characterization}

All fractions were characterized phytochemically by thin layer chromatography (TLC) on silica gel plates, using as mobile phase hexane-ethyl acetate (7:3), chloroform-methanol (9:
1), and BAW (n-butanol-acetic acid-water; 4:1:5). These fractions were selected according to the phytochemical profile, resulting in four fractions of each crude methanol extract and ethyl acetate. After, each of them was tested in TLC for observation of white halos in the plates by acetylcholinesterase enzymatic activity. Only a few samples were selected to be purified on a silica gel and Sephadex LH-20 column. Two ethyl acetate fractions (AF1 and AF2) were applied to a silica gel column, using as mobile phase hexane-ethyl acetate (7:3), chloroform-methanol $(9: 1)$, and methanol. Thereafter, the fractions AF1.1, AF1.2, AF1.3, $\mathrm{AF} 1.4$, and AF2.1, AF2.2, AF2.3, AF2.4, AF2.5 were obtained and equally tested in TLC. After that, only AF1.1 and AF2.5 samples were applied again to the silica gel column, using different mobile phases. AF1.1-2 and AF-2.5-2 were then acquired and again tested in TLC for observation of white halos occurrence as well; therefore, these fractions were employed in quantitative enzymatic tests to acetylcholinesterase inhibition. The MF2 fraction from methanol extract was applied to Sephadex column for purification, using methanol as mobile phase. After TLC analysis with chloroformmethanol (9:1) eluent, the MF2-3 fraction was obtained.

\section{Chromatographic analyzes by TLC}

Samples from 15 fractions of methanol and 30 fractions of ethyl acetate were solubilized in methanol at a concentration of $1 \mathrm{mg} / \mathrm{mL}$, then applied to TLC $\left(10 \times 20 \mathrm{~cm}, \mathrm{Si}_{250} \mathrm{~F}()\right.$ with $\mathrm{BAW}$ (n-butanol-acetic acid-water; 4:1:5) as mobile phase, and visualized by UV lamps (254 and $365 \mathrm{~nm}$ ) with sulfuric vanillin. After this procedure, fractions were pooled into for methanol and four ethyl acetate portions by the coloring observed on the plate.

Acetylcholinesterase inhibitors were characterized according to the methodology described by MARSTON et al. (2002), employing acetylcholinesterase enzyme (500 $\mathrm{U}$ ) dissolved in 75 $\mathrm{mL}$ of $0.05 \mathrm{M}$ Tris-HCl buffer ( $\mathrm{pH} 7.8$ ), adding bovine serum albumin (BSA) $(75 \mathrm{mg})$ for enzyme stabilization (solution already prepared). The previously prepared samples of methanol and ethyl acetate fractions of $M$. elliptica Martius leaves were employed in TLC $\left(5 \times 10 \mathrm{~cm}, \mathrm{Si}_{250} \mathrm{~F}{ }^{\circledR}\right)$ with hexaneEtOAc (7:3), chloroform-methanol (9:1), and BAW (n-butanol: acetic acid: water, 4:1:5) as mobile phase.

After drying, the eluted plates were sprinkled with the enzyme stock solution and dried again, followed by incubation, where they were kept in an air-conditioned chamber at $37{ }^{\circ} \mathrm{C}$ for 20 
minutes for enzyme stabilization. For enzyme detection, the solutions of 1-naphthyl acetate (25 $\mathrm{mg})$ with ethanol (10 mL) (A), and Fast Blue B salt (100 mg) with distilled water $(40 \mathrm{~mL})(B)$ were employed (solutions already prepared). Immediately after incubation, $1 \mathrm{~mL}$ solution $\mathrm{A}$ and $4 \mathrm{~mL}$ solution $B$ were mixed and sprinkled onto the plates for the observation of white inhibition halos, after some time.

This test is based on the cleavage of 1naphthyl acetate by acetylcholinesterase to form 1naphthol, which reacts with the Fast Blue B salt to generate the diazonium purple coloration. This method provides fast access to information on the enzyme activity and its location on the plant; it is because the separated constituents can be directly detected on TLC plates since plate regions containing acetylcholinesterase inhibitors appear as white marks on a purple background (MARSTON et al., 2002).

\section{Acetylcholinesterase enzyme activity}

Crude extract and fractions used in inhibition tests were prepared in methanol or ethyl acetate, as the solvent used in crude extract obtainment. Six concentrations were adopted, with an initial stock solution at $20 \mu \mathrm{g} / \mathrm{mL}$, and the remaining concentrations were reached by serial dilution $(10,5,2.5,1.25$, and $0.625 \mu \mathrm{g} / \mathrm{mL})$.

The acetylcholinesterase activity was in vitro tested in 96-well microplates, as adapted from the method developed by Ellman (1961). The enzyme hydrolyzes acetylthiocholine to give thiocholine, which reacts with DTNB to produce 2nitrobenzoate-5-mercapto-thiocholine and 5-thio-2nitrobenzoate that can be detected at $405 \mathrm{~nm}$. In 96well microplates, the following measurements were added at each concentration in the first stage: $88-\mu \mathrm{L}$ phosphate buffer, $2-\mu \mathrm{L}$ inhibitor, and $10-\mu \mathrm{L}$ enzyme (sample). For eserine control, $88 \mu \mathrm{L}$ and $2 \mu \mathrm{L}$ of eserine and $10 \mu \mathrm{L}$ enzyme were deployed. In the inhibitor blank, $98-\mu \mathrm{L}$ phosphate buffer, $2-\mu \mathrm{L}$ inhibitor, $88-\mu \mathrm{L}$ eserine blank control, $2-\mu \mathrm{L}$ pure water, and $10 \mu \mathrm{L}$ enzyme was added, and then taken to a B.O.D. for 10 minutes. Subsequently, further 70 $\mu \mathrm{L}$ of phosphate buffer was poured into the filled wells, and then $100 \%$ enzyme activity control was also included together with $160 \mu \mathrm{L}$ phosphate buffer, $10 \mu \mathrm{L}$ enzyme, and blank enzyme $170 \mu \mathrm{L}$ of phosphate buffer. In the second stage, in all wells, the following compounds were added: $10 \mu \mathrm{L}$ of DTNB and $25 \mu \mathrm{L}$ of ACTI and taken to B.O.D. for 60 minutes, after which the plate was read in ELISA reader. The methanol solvent and ethyl acetate were controlled to verify whether they could interfere with inhibition; as a result, neither of them showed significant results for acetylcholinesterase enzymatic inhibition.

The eserine inhibitor, also known as physostigmine, was used as a positive control of acetylcholinesterase inhibition. The dose-response curve for eserine was built from a $20 \mu \mathrm{g} / \mathrm{mL}$ concentration with serial dilutions, obtaining six concentrations. With that, the inhibition curve was plotted for inhibition percentage versus eserine concentration logarithm. Non-linear regression parameters were plotted for each curve, and $\mathrm{IC}_{50}$ values were netted using SigmaPlot software.

\section{Acetylcholinesterase enzymatic inhibition percentage}

Enzyme inhibition percentages were calculated by comparing the absorbance of samples (assay containing extract + enzyme + substrate + DTNB) with enzyme control (assay containing buffer + enzyme + substrate + DTNB). The values corresponding to enzyme control absorbance provided the benchmark for maximum activity of the employed enzyme in experiments, i.e. the maximum enzyme capacity for product formation from substrates, being considered an enzyme activity of $100 \%$. For calculation, we used the following equation: $\%$ inhibition $=[(\mathrm{C}-\mathrm{A}) \times 100] /$ C), wherein: $\mathrm{C}$ represents the enzyme control absorbance subtracted from the blank, and A is the sample absorbance subtracted by extract blank (plant extract + substrate + buffer + DTNB).

\section{$\alpha$-Amylase enzymatic inhibition percentage}

The assay was performed through an adaptation of the method proposed by Bernfeld (1955). The inhibition was observed based on maltose formation, which results from this enzyme action on the starch present in the medium. Maltose reduces DNS producing an orange colored product, whose absorbance is determined at $540 \mathrm{~nm}$.

Porcine pancreatic $\alpha$-amylase was dissolved in $20 \mathrm{mM}$ sodium buffer $(\mathrm{pH}$ 6.9). In 96-well microplates, the following measures were added 2.4 $\mu \mathrm{L}$ sodium phosphate buffer, $2.1 \mu \mathrm{L}$ inhibitor, and $8.25 \mu \mathrm{L}$ enzyme, performed in a water bath at $25^{\circ} \mathrm{C}$ for 10 minutes. Afterwards, $8.25 \mathrm{~g} 1 \%$ starch was added and taken to a water bath at $25^{\circ} \mathrm{C}$ for 20 minutes. In the inhibitor blank, $10.6 \mu \mathrm{L}$ buffer and $2.1 \mu \mathrm{L}$ inhibitor were added, and then $88 \mu \mathrm{L}$ DNS was included for both inhibitor and inhibitor blank, being boiled for 5 minutes and placed in an ice bath until room temperature. Then, $250-\mu \mathrm{L}$ water was added for reading at $540 \mathrm{~nm}$. For $100 \%$ control enzyme activity, $4.5 \mu \mathrm{L}$ phosphate buffer, $8.25 \mu \mathrm{L}$ 
enzyme, and $8.25 \mu \mathrm{L}$ starch were employed; hereafter, it was heated at $25^{\circ} \mathrm{C}$ for 20 minutes. In addition, $12.7 \mu \mathrm{L}$ phosphate buffer and $8.25 \mu \mathrm{L}$ enzyme were added to the enzyme blank. In both samples, $88 \mu \mathrm{L}$ DNS was poured and boiled for 5 minutes and then taken to an ice bath, and $250 \mu \mathrm{L}$ of water was applied to each sample and reading was conducted.

Acarbose inhibitor was used as a positive control of $\alpha$-amylase inhibition. The dose-response curve for eserine was built from a $100 \mu \mathrm{g} / \mathrm{mL}$ concentration with serial dilutions, obtaining six concentrations. With that, the inhibition curve was plotted for inhibition percentage versus acarbose concentration logarithm.

Enzyme inhibition percentages were estimated by comparing the absorbance of samples (assay containing extract + enzyme + substrate + DTNB) with the enzyme control (assay containing buffer + enzyme + substrate + DTNB). The values corresponding to enzyme control absorbance provided the benchmark for maximum activity of the employed enzyme in experiments, i.e. the maximum enzyme capacity for product formation from substrates, being considered an enzyme activity of $100 \%$. For calculation, we used the following equation: \% inhibition $=[(\mathrm{C}-\mathrm{A}) \times 100] /$ $\mathrm{C})$, wherein: $\mathrm{C}$ represents the enzyme control absorbance subtracted from the blank, and A is the sample absorbance subtracted by extract blank (plant extract + substrate + buffer + DTNB).

In this case, starch was not used in the inhibitor blank because of gelatinization at high temperatures. Such phenomenon causes granule swelling and disruption, followed by amylose release and viscosity increase (SILVA, et al., 2004).

\section{Influence of solvents used in plant extracts dilution}

Inert solvents were chosen for the study of the inhibitory action of plant extracts with different polarities. The amount of solvent employed to solubilize plant extracts samples was evaluated before acetylcholinesterase and $\alpha$-amylase activities under the same conditions described for enzymatic determination experiments. Methanol and ethyl acetate solvents were tested during sample assays on a microplate. Neither of the solvents inhibited the activity of any of the enzymes.

\section{Statistics}

The concentration of each sample was analyzed in triplicate and the obtained results were presented as means with respective standard deviations. The obtained results were compared to control to identify the means. The level of significance for all statistical analyses was $5 \%(\mathrm{p}<$ 0.05 ), therefore, resulting in a $95 \%$ confidence interval.

\section{RESULTS AND DISCUSSION}

\section{Chemical profile characterization and bioactivity test}

Plants are composed of secondary metabolites from several classes; their concentration and presence are influenced by genetics, abiotic environmental factors, as well as plant and leaf ages (ESTELL; FREDRIKSON; JAMES, 2016). A chemical characterization of these metabolites can be made by several methods. In this study, extracts were obtained through solvents with different polarities, such as methanol and ethyl acetate. Polar and medium polarity substances are extracted respectively in these solvents types. To characterize these extracts, chromatographic techniques, chemical and enzymatic reactions were needed.

Figures 1A and 1B show the chemical profile by TLC of methanol extract and ethyl acetate fractions, respectively, both eluted with BAW. By applying vanillin sulfuric onto the plates, several substances exhibited coloring reactions indicating tannins (red), flavonoids (yellow), and terpenes (blue). The fractions were merged by each fraction chemical profile, transforming each extract into four fractions for fractionation and purification continuance. In Figures 2A, 2B, 3A, and 3B, substances absorbed under UV light $-254 \mathrm{~nm}$ (Figure2A and 3A) and $365 \mathrm{~nm}$ (Figure 2B and 3B) were noticed. White halos can be seen in Figures $4 \mathrm{~A}, 4 \mathrm{~B}, 4 \mathrm{C}, 5 \mathrm{~A}, 5 \mathrm{~B}$, and $5 \mathrm{C}$, which is an indication of acetylcholinesterase inhibition.

\section{Acetylcholinesterase enzyme inhibition}

The inhibition of acetylcholinesterase enzyme activity was assessed by Ellman method, which is based on acetylthiocholine hydrolysis by acetylcholinesterase, forming thiocholine that reacts with DTNB and forms a yellow 5-thio-2-nitrobenzoate colorimetric agent.

Such inhibition could be observed in both crude methanol extract and ethyl acetate; however, it was more significant in methanol extract. Methanol extract showed a powerful inhibitory action of $68 \%$ with an $\mathrm{IC}_{50}$ of $12.43 \mu \mathrm{g} / \mathrm{mL}$, whereas for ethyl acetate it was only $40 \%$ (Figure 6). Both for methanol and ethyl acetate extracts, the inhibition varies with dosage; therefore, once extract concentration is raised the inhibitory effect also increases. 

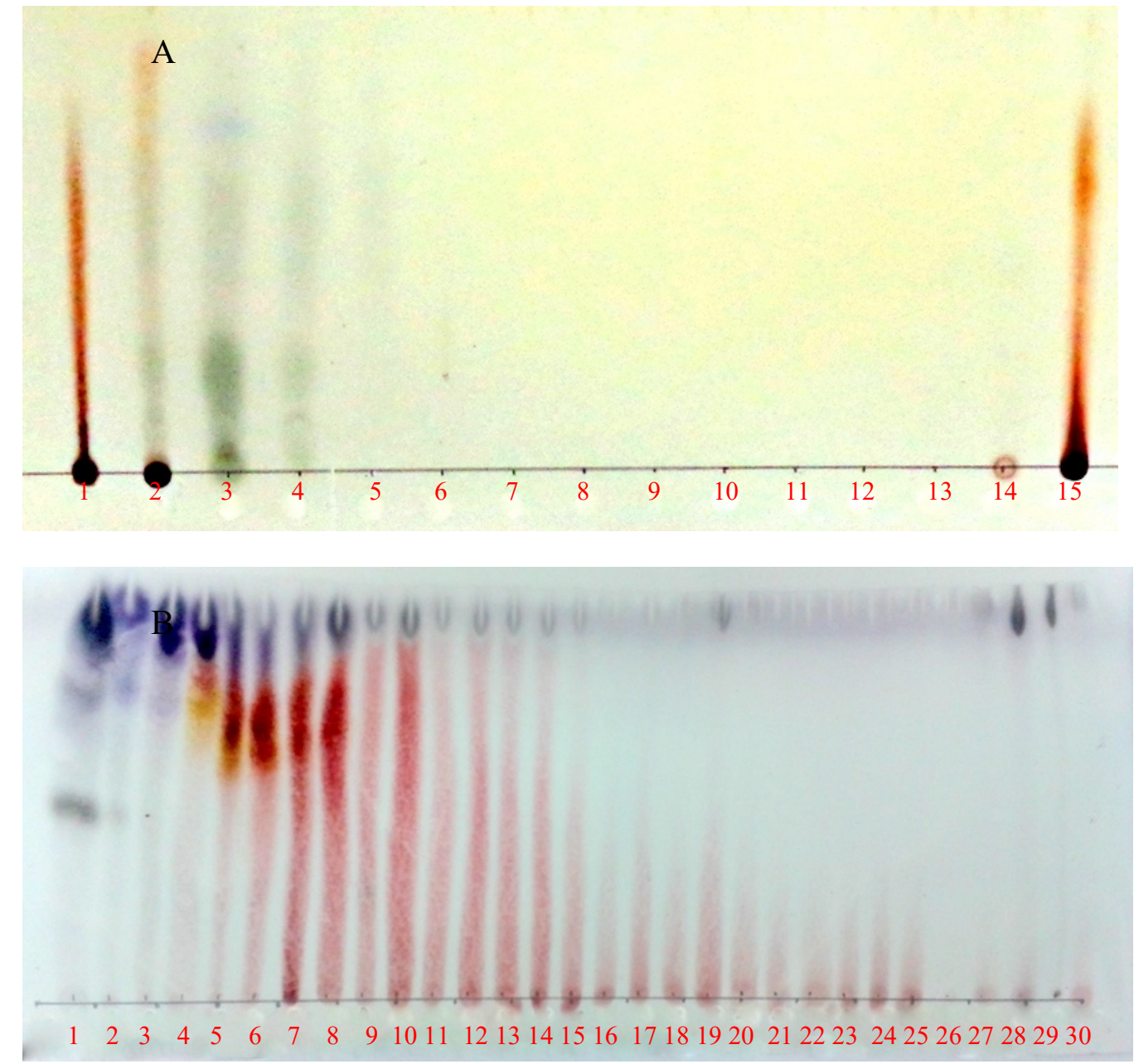

Figure 1. TLC of methanol and ethyl acetate extracts respectively from Mouriri elliptica Martius leaves. Mobile Phase: BAW; Developer: vanillin sulfuric. 


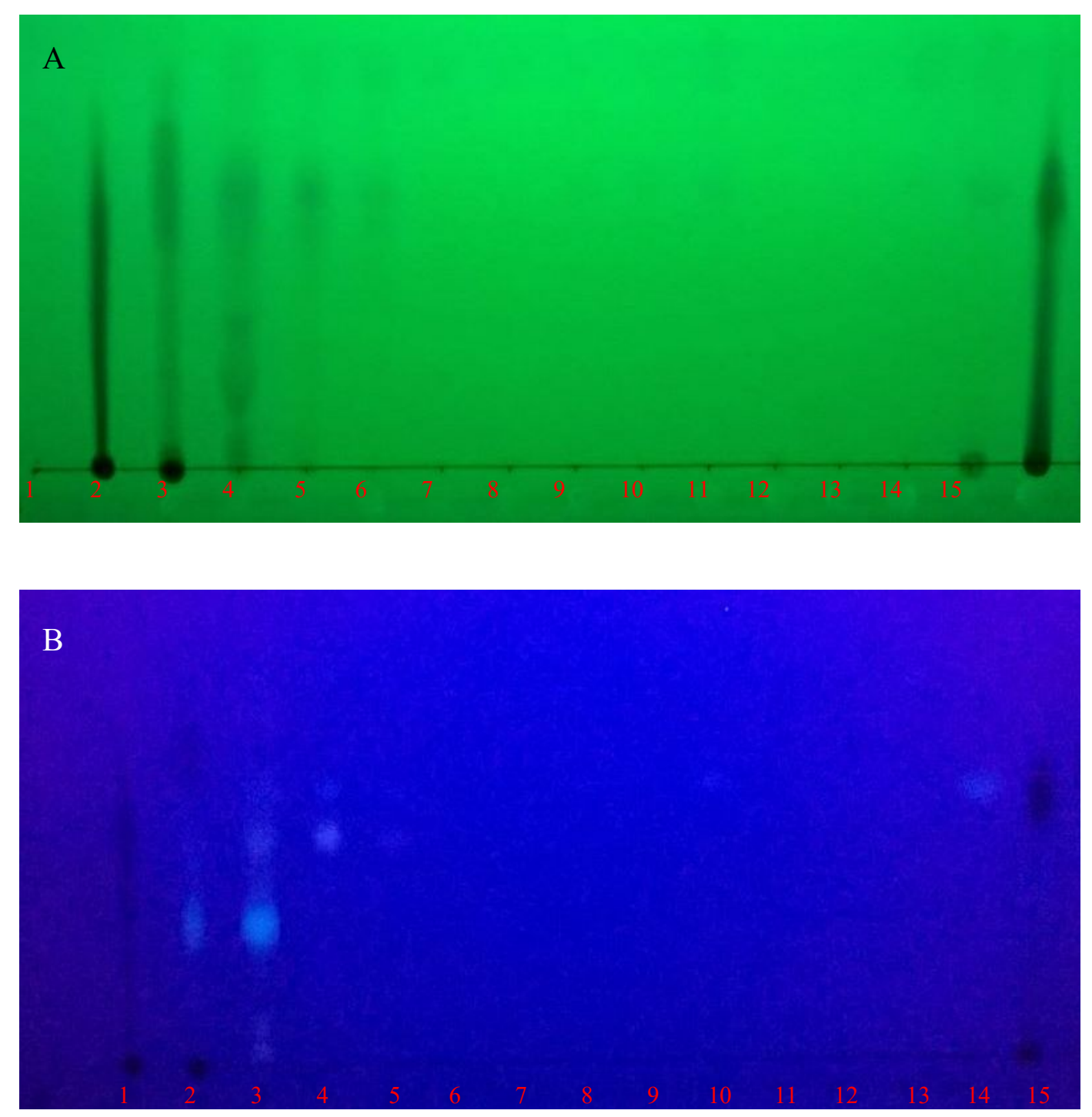

Figure 2. TLC of methanol extract from Mouriri elliptica Martius species. Mobile Phase: BAW; Developer A - UV 254 nm; B-UV 365 nm. 

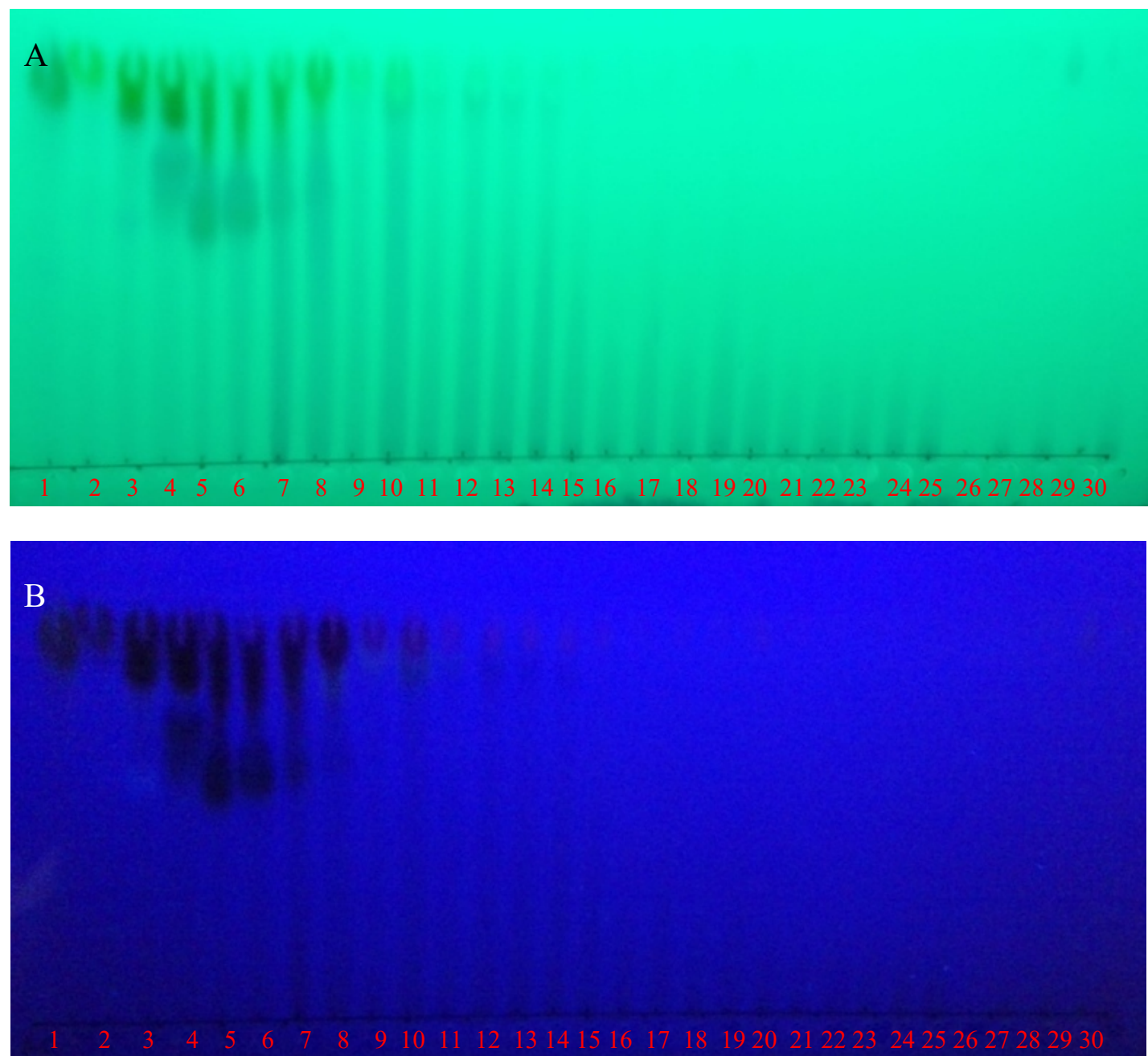

Figure 3. TLC of ethyl acetate extract from Mouriri elliptica Martius species. Mobile Phase: BAW; Developer A - UV 254 nm; B-UV 365 nm.

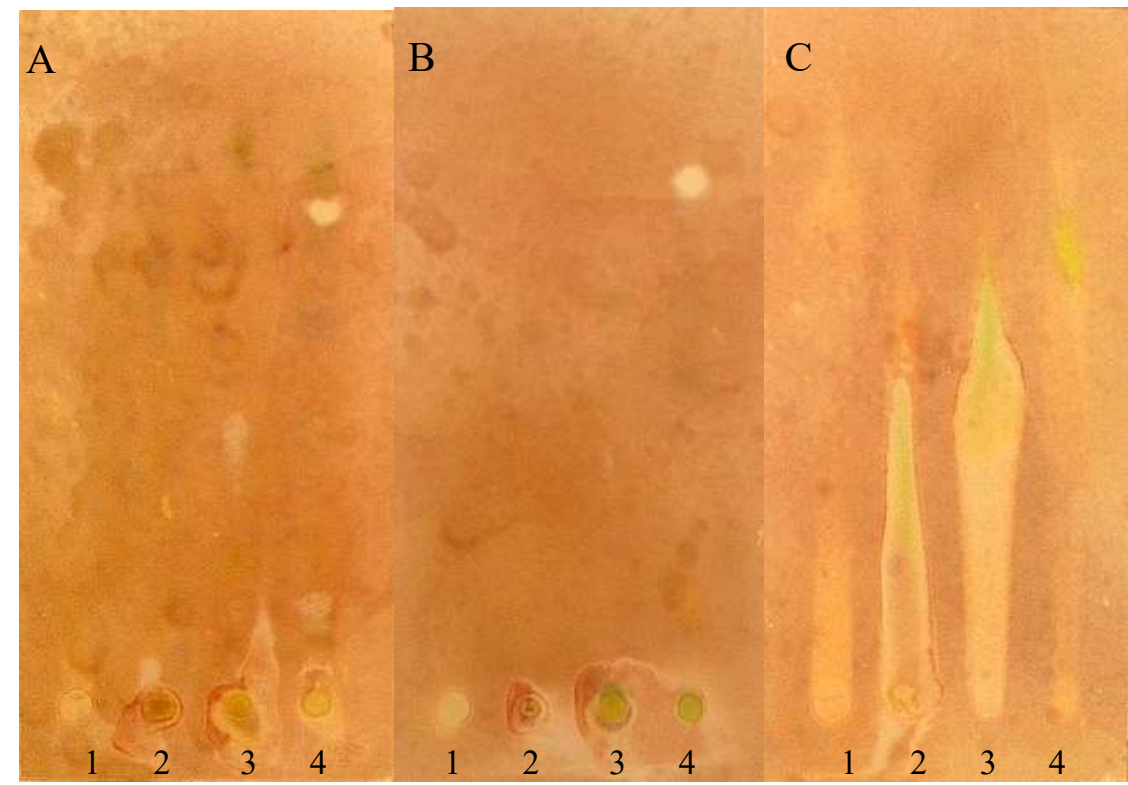

Figure 4. TLC of fractions from ethyl acetate extract from Mouriri elliptica Martius species.

Mobile Phases: A -hexane-EtOAc (7: 3), B - $\mathrm{CHCl}_{3}-\mathrm{MeOH}$ (9: 1), and C-BAW; Developer: AChE / Naphthyl / Fast Blue B salt. 


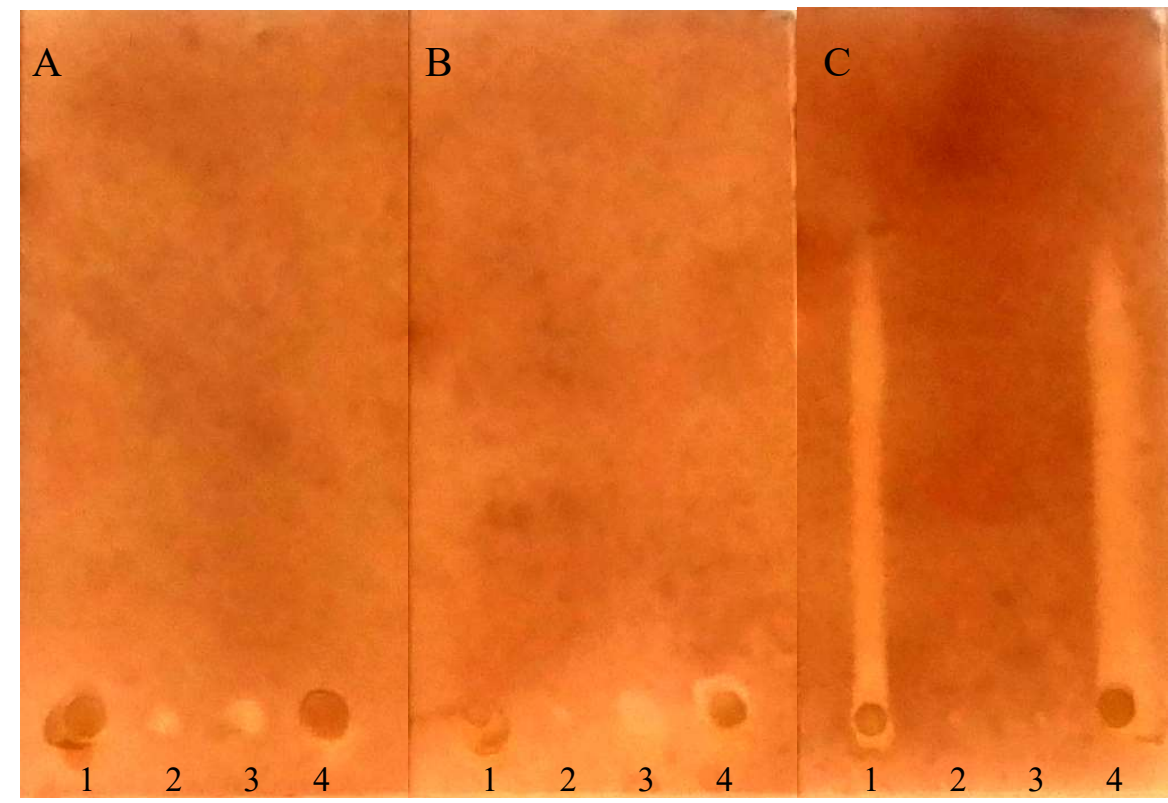

Figure 5. TLC of fractions from methanol extract from Mouriri elliptica Martius species.

Mobile Phases: A -hexane-EtOAc (7: 3), B - $\mathrm{CHCl}_{3}-\mathrm{MeOH}$ (9: 1), and C-BAW; Developer: AChE / Naphthyl / Fast Blue B salt.

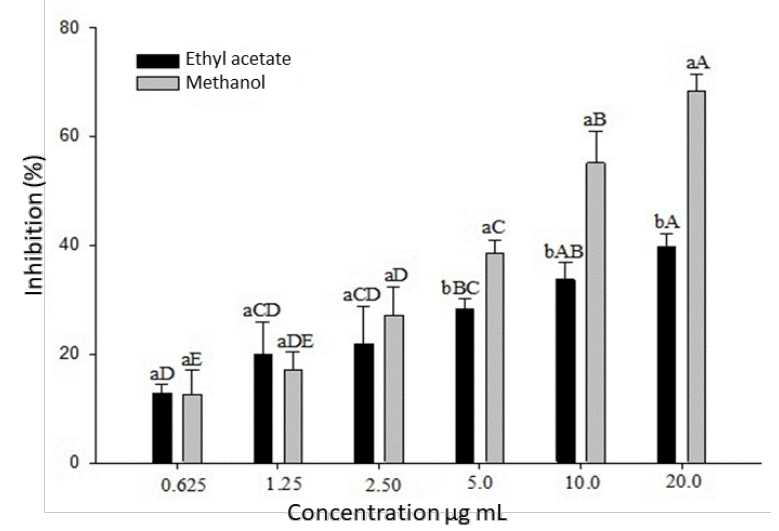

Figure 6. Acetylcholinesterase inhibition percentage of ethyl acetate and methanol crude extracts.

The results were expressed as the triplicate mean. a and b: significant difference between extracts. A, B, C, D: significant difference among concentrations of each extract.

A dose-response curve was built for the same extracts concentrations using eserine as a positive control, with an inhibition rate of $86 \%$ and $\mathrm{IC}_{50}$ of $1.37 \mu \mathrm{g} / \mathrm{mL}$. The eserine, or physostigmine, is a short-acting reversible inhibitor of acetylcholinesterase enzyme. This substance is an indole alkaloid extracted from Physostigma venenosum plant species (MUKHERJEE, et al., 2007).

Fractions of M. elliptica leaves were also evaluated on acetylcholinesterase inhibition. The results have demonstrated that all extracts of this plant species were capable of influencing enzyme action. MF1 and MF4 fractions (Figure 7) unveiled a relevant inhibition above $70 \%$ with a respective
$\mathrm{IC}_{50}$ value of 4.68 and $4.18 \mu \mathrm{g} / \mathrm{mL}$. However, fraction AF3 was higher than $40 \%$, the other fractions inhibited between 40 and $20 \%$ of the enzyme activity (Figure 8 ). The mean of doses for each extract are graphically expressed in Figures 7 and 8 ; they a lack of any significant differences between the inhibition percentages of crude extract and of fractions, for both methanol and ethyl acetate extracts. Even some fractions have presented a higher inhibition percentage than crude extract, but when statistically analyzed this perceptual is not relevant. For further studies on acetylcholinesterase enzymatic inhibition, it would be more feasible to use crude extract, as it is more easily obtained compared to the fractions. 
For acetylcholinesterase, plant species with an inhibitory action above $50 \%$ are considered as powerful inhibitors; between 30 and $50 \%$, they are classified as moderate; while below $30 \%$, they are regarded as low (VINUTHA et al., 2007).

Previous studies have reported that $M$. elliptica leaves contain saponins and tannins in small amounts, besides terpenes and flavonoids such as kaempferol, quercetin, and myricetin (ANDREO, 2008). In the literature, flavonoids have been reported to carry an acetylcholinesterase inhibitory action (LAU, LEE, CHIN, 2014). Plant species belonging to the genus Rhizophora spp. have the same secondary compounds as does M. elliptica; the methanol extract of those plants is known for showing a higher acetylcholinesterase inhibitory action if compared to those of hexane and ethyl acetate extracts (WAHYUNI; DARUSMAN; SURYA, 2015).

The organic fractions of extracts from other plant species such as Achyrocline tomentosa, Eupatorium viscidum, Ruprechtia apetala, Reptans trichocline, and Zanthoxylum coco have been reported to exhibit an inhibitory action on acetylcholinesterase (CHEN et al., 2012). Even though we found a moderate inhibitory action in $M$. elliptica ethyl acetate extract, there are no scientific reports on plant species of the same family showing acetylcholinesterase enzyme inhibition.

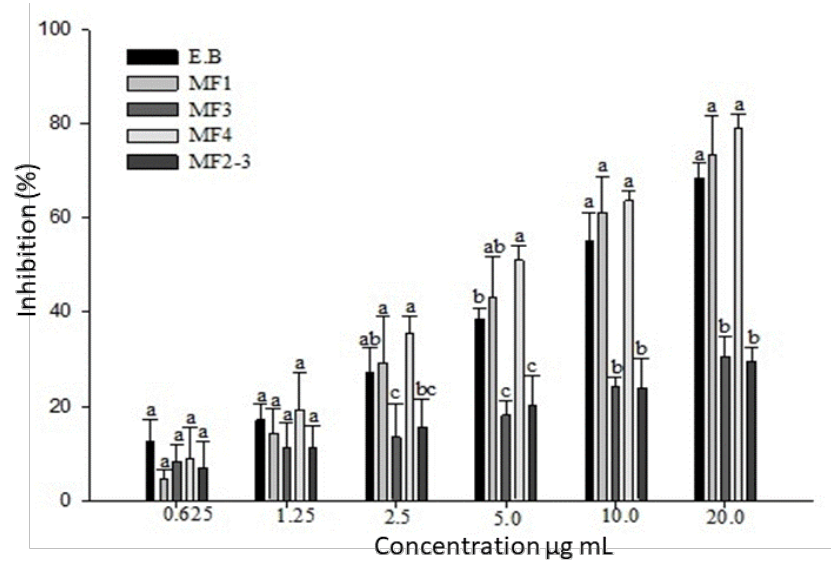

Figure 7. Acetylcholinesterase inhibition percentage of methanol extract fractions.

The results were expressed as the mean of all doses in triplicate.

$a$ and $b$ : significant difference between extracts.

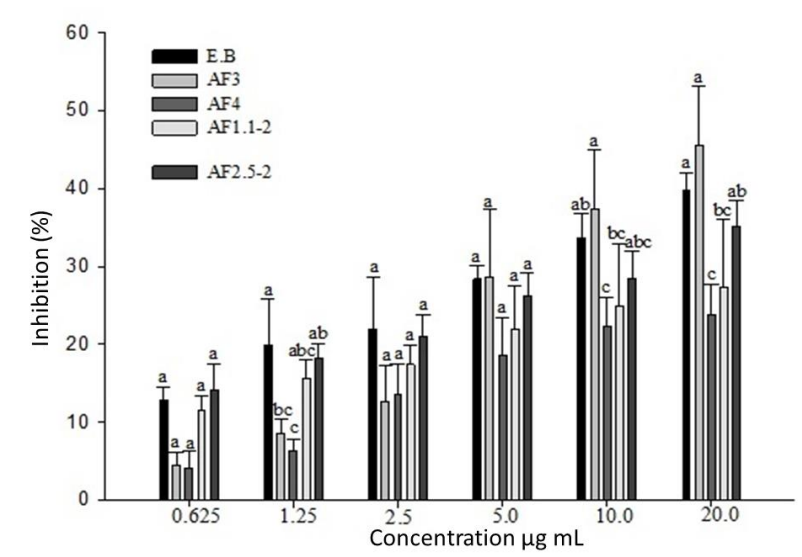

Figure 8. Acetylcholinesterase inhibition percentage of ethyl acetate extract fractions.

The results were expressed as the mean of all doses in triplicate

$\mathrm{a}$ and $\mathrm{b}$ : significant difference between extracts. 


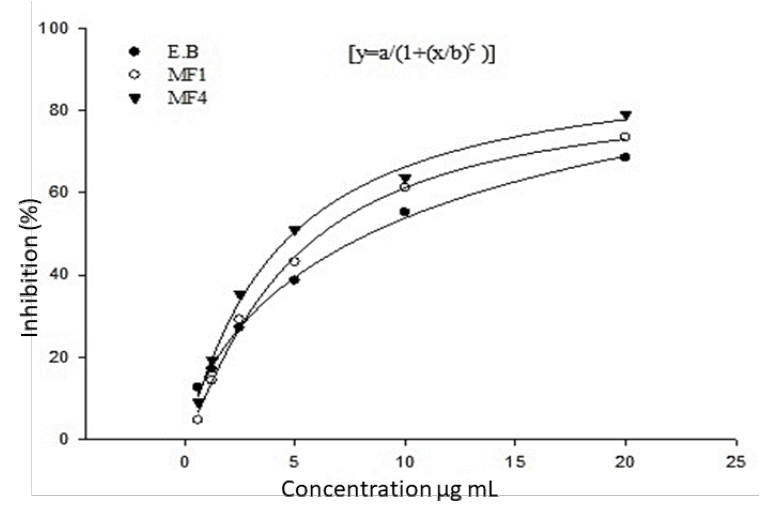

Figure 9. $\mathrm{IC}_{50}$ of methanol crude extract and fractions.

Doses: EB - $12.43 \mu \mathrm{g} / \mathrm{mL}, \mathrm{MF} 1-4.68 \mu \mathrm{g} / \mathrm{mL}, \mathrm{MF} 4-4.18 \mu \mathrm{g} / \mathrm{mL}$. Each point presents the mean in triplicate.

In determining the nature of an inhibition process, the $\mathrm{Ki}$ magnitude is estimated (MARANGONI, 2003); thus, the inhibition model, which may be a competitive and non-competitive inhibition, is then ascertained (DJERIDANE, et al., 2015). The $\mathrm{Ki}$ is one of the kinetic parameters of an enzymatic activity, also known as the dissociation constant (MARANGONI, 2003). In this present study, this parameter was calculated for each extract type and analyzed in triplicate with their respective standard deviation (Table 1).

The lower the Ki value, the more inhibitory the compound is, indicating a high affinity with the enzyme. The methanol extract samples reached a minimal Ki, the fractions MF3 and MF2.3 showed the same Ki (0.005). Yet, the ethyl acetate samples featured higher values, and AF1.1-2 and AF2.5-2 fractions were the most significant among all samples, with respective values of 1.369 and 1.580 (Ki). Based on these data, although the MF3 fraction presented an inhibition percentage above $70 \%$, the second highest, it also exhibited a minimal Ki. Therefore, this was a fraction with a high affinity with acetylcholinesterase enzyme.

Table 1. Dissociation constant (Ki) of acetylcholinesterase of different extracts.

\begin{tabular}{ll}
\hline Extract & Ki $(\boldsymbol{\mu g} / \mathbf{~ m L ~})$ \\
\hline E.g. B.M. & $0.017( \pm 0.010)$ \\
MF1 & $0.022( \pm 0.018)$ \\
MF3 & $0.005( \pm 0.006)$ \\
MF4 & $0.015( \pm 0.005)$ \\
MF2.3 & $0.005( \pm 0.005)$ \\
E.g. B. A & $3.014( \pm 2.459)$ \\
AF3 & $11.456( \pm 2.723)$ \\
AF4 & $2.409( \pm 2.050)$ \\
AF1.1-2 & $1.369( \pm 0.969)$ \\
AF2.5-2 & $1.580( \pm 0.766)$ \\
\hline
\end{tabular}

\section{a-amylase enzyme inhibition}

Methanol and ethyl acetate crude extracts were also evaluated for $\alpha$-amylase inhibitory action. Our findings showed an inhibitory action of $50 \%$ for ethyl acetate extract at the highest dose, whereas the inhibitory action of methanol extract was not significant (Figure 10). Moreover, while there were no differences among the concentrations of methanol extract, ethyl acetate concentrations had differences from one to another.

Flavonoids are commonly found in the plant species used for extracts; this is a compound described in the literature as $\alpha$-amylase enzyme inhibitor (TADERA, et al., 2006). Furthermore, tannins are also detected in the leaves of this species; this substance plays a role in protein precipitation, forming insoluble compounds that bind to digestive enzymes such as $\alpha$-amylase (ZAJACZ, et al., 2007). Therefore, the action of $M$. elliptica leaf extract should be partially attributed to the high contents of tannins, as observed in chromatographic analyses.

The inhibitory action on $\alpha$-amylase in plants can be related to secondary compounds, such as phenolic compounds, tannins, and triterpenoids (ALI; HOUGHTON; SOUMYANATH, 2006). 
Nonetheless, no studies have been carried out on $\alpha$ amylase inhibition by plant species from Mouriri genus. In our assays, we used acarbose as a positive control on $\alpha$-amylase enzyme activity. From this, a dose-response curve with concentrations of acarbose between 0 and $100 \mu \mathrm{g} / \mathrm{ml}$ was constructed, achieving an inhibition of up to $49.89 \%$.

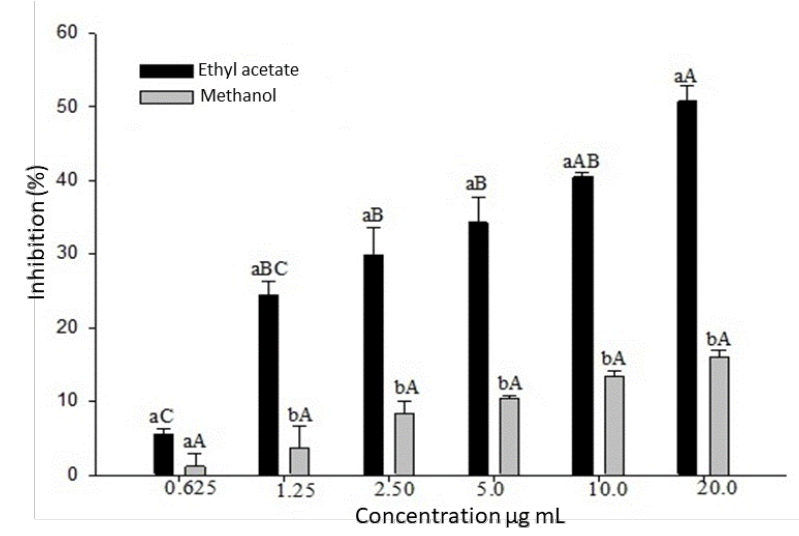

Figure 10. $\alpha$-amylase inhibition percentage by crude extracts of ethyl acetate and methanol.

The results were expressed as the mean of triplicates. a and b: significant among between extracts A, B, C: significant difference among concentrations of each extract.

\section{CONCLUSION}

The species Mouriri elliptica is a promising source of bioactive compounds, showing inhibitory action on acetylcholinesterase and $\alpha$-amylase enzymes. Methanol extract proved to be a powerful inhibitor of acetylcholinesterase enzyme, as ethyl acetate extract did for the $\alpha$-amylase enzyme. Based on this study, this plant species becomes a potential agent for pest control; thus, it should be adopted in the farming sector, as well as for further in vivo studies. The findings also helped to increase knowledge on this species, which is lacking in the scientific literature.

\section{ACKNOWLEDGEMENTS}

We would like to thank the Brazilian agencies FINEP, CNPq, and CAPES, and the Instituto Federal de Educação, Ciência e Tecnologia Goiano (IF Goiano) for providing financial support.

RESUMO: O crescimento populacional tem aumentado a quantidade de produção alimentícia, sendo necessárias novas fontes para o aumento da quantidade e qualidade dos produtos agrícolas. Os carbamatos e organofosforados são classes de inseticidas utilizadas em todo o mundo, são inibidores da acetilcolinesterase (AChE). Os vegetais possuem uma resistência natural aos insetos, e esse método de resistência pode ser utilizado no controle das pragas como uma nova alternativa para redução do uso de inseticidas químicos, tais como os inibidores da $\alpha$-amilase, enzima digestiva, a qual sua inibição prejudica o crescimento e desenvolvimento de espécies de pragas. $\mathrm{E}$ os inibidores da acetilcolinesterase que danificam o funcionamento normal do Sistema Nervoso Central e Periférico, através de elevadas concentrações da acetilcolina que ficam depositadas nas sinapses colinérgicas. Este acúmulo de ACh provoca uma grande estimulação que leva á alterações comportamentais, asfixia, hiperatividade e a morte. Estudos já realizados mostraram que os agrotóxicos botânicos têm vantagens sobre os sintéticos, sendo degradados rapidamente no meio ambiente. Neste cenário os vegetais têm desempenhado um importante papel no controle de pragas, através da síntese de novas moléculas para uso na agricultura. $O$ presente trabalho avaliou a inibição das enzimas acetilcolinesterase e $\alpha$-amilase através do método da microplaca a partir dos extratos das folhas de Mouriri elliptica Martius em diferentes polaridades.

PALAVRAS-CHAVES: Cerrado. Inibição enzimática. Pesticidas botânicos. Cromatografia. 


\section{REFERENCES}

ALI, H.; HOUGHTON, P. J; SOUMYANATH, A. Alpha-Amylase inhibitory activity of some Malaysian plants used to treat diabetes; with particular reference to Phyllanthus amarus. Journal of Ethnopharmacology, v.107, n.3, p. 449, 2006. https://doi.org/10.1016/j.jep.2006.04.004

ANDREO, M. A. Prospecção químico-farmacológica em plantas superiores: estudo químico e atividade sobre o sistema gastrintestinal de Mouriri pusa Gardner e Mouriri elliptica Martius (Melastomataceae). 2008.106f. Tese (Doutorado em Química) - Curso de Pós-Graduação em Genética e Bioquímica, Universidade Estadual Paulista Julio de Mesquita Filho, Araraquara, 2008.

BERNFELD, P. Amylases, alpha and beta. In: COLOWICK, S. P. and KAPLAN, N. O. (Eds.). Methods in enzymology. New York: Academic Press, 1955, v. 1. p. 149-158. https://doi.org/10.1016/0076-6879(55)010215

CHEN, J.; QUAN, M. H.; CHENG, Y. Q.; SUN, J.; LI, L.T. Acetylcholinesterase inhibitory activity of Chinese sufu (fermented tofu) ethanol-extract. Food Chemistry, v. 134, n. 3, p. 1263-1266, 2012.

https://doi.org/10.1016/j.foodchem.2012.02.141

DJERIDANE, A.; HAMDI, A.; BENZANIA, W.; CHEIFA, K.; LAKHDARI, I.; YOUSFI, M. The in vitro evaluation of antioxidative activity, $\alpha$-glucosidase, $\alpha$-amylase enzyme inhibitory of natural phenolic extracts. Diabetes and Metabolic Syndrome: Clinical Research and Reviews, v.9, n. 4, p. 324-331, 2015. https://doi.org/10.1016/j.dsx.2013.10.007

ELLMAN, G. L.; COURTNEY, K. D.; ANDRES JUNIOR, V.; FEATHERSTONE, R. M. A new rapid colorimetric determination of acetylcholinesterase activity. Biochemical Pharmacology, v. 7, n. 2, p. 88-95, 1961. https://doi.org/10.1016/0006-2952(61)90145-9

ESTELL, R. E.; FREDRICKSON, E. L.; JAMES, D. K. Effect of light intensity and wavelength on concentration of plant secondary metabolites in the leaves of Flourensia cernua. Biochemical Systematics and Ecology, v. 65, p. 108-114, 2016. https://doi.org/10.1016/j.bse.2016.02.019

KNAAK, N.; FIUZA, L. M. Potential of essential plant oils to control insects and microorganisms. Neotropical Biology and Conservation, v. 5, n. 2, p.120-132, 2010. https://doi.org/10.4013/nbc.2010.52.08

KHALIQ, A.; KHAN, A. A.; AFZAL, M.; TAHIR, H. M.; RAZA, A. M.; KHAN, A. M. Field evaluation of selected botanicals and commercial synthetic insecticides against Thrips tabaci Lindeman (Thysanoptera: Thripidae) populations and predators in onion field plots. Crop Protection, v. 62, p. 10-15, 2014. https://doi.org/10.1016/j.cropro.2014.03.019

LAMBRAÑO, R. H.; CASTRO, N. P.; GALLARDO, K. C.; STASHENKO, E.; VERBEL, J. O. Essential oils from plants of the genus Cymbopogon as natural insecticides to control stored product pests. Journal of Stored Products Research, v. 62, p. 81-83, 2015. https://doi.org/10.1016/j.jspr.2015.04.004

LARSEN, K. E.; LIFSCHITZ, A. L.; LANUSSE, C. E.; VIRKEL, G. L. The herbicide glyphosate is a weak inhibitor of acetylcholinesterase in rats. Environmental Toxicology and Pharmacology, v. 45, p. 41-44, 2016. https://doi.org/10.1016/j.etap.2016.05.012

LAU, K. W.; LEE, S. K.; CHIN, J. H. Effect of methanol leaves extract of Clinacanthus nutans on the activity of acetylcholinesterase in male mice. Journal of Acute Disease, v.3, n.1, p. 22-25, 2014.

https://doi.org/10.1016/S2221-6189(14)60005-6

MARANGONI, A. G. Enzyme Kinetics: A Modern Approach. New Jersey: John Wiley \& Sons, 2003, p.65. 
MARSTON, A. KISSLING, J.; HOSTETTMANN, K. A. A rapid TLC bioautographic method for the detection of acetylcholinesterase and butyrylcholinesterase inhibitors in plants. Phytochemical Analysis, v.13, n. 1, p.51-54, 2002. https://doi.org/10.1002/pca.623

MEHRABADI, M.; BANDANI, A. R.; MEHRABADI, R.; ALIZADEH, H. Inhibitory activity of proteinaceous $\alpha$-amylase inhibitors from Triticale seeds against Eurygaster integriceps salivary $\alpha$-amylase: Interaction of the inhibitors and the insect digestive enzymes. Pesticide Biochemistry and Physiology, v. 102, n. 3, p. 220-228, 2012. https://doi.org/10.1016/j.pestbp.2012.01.008

MIRESMAILLI, S.; ISMAN, M. B. Botanical insecticides inspired by plant-herbivore chemical interactions. Trends in Plant Science, v. 19, n. 1, p.29-35, 2014. https://doi.org/10.1016/j.tplants.2013.10.002

MUKHERJEE, P. K.; KUMAR, V.; HOUGHTON, P. J. Screening of Indian medicinal plants for acetylcholinesterase inhibitory activity. Phytotherapy Research, v. 21, n. 12, p. 1142-1145, 2007. https://doi.org/10.1002/ptr.2224

SILVA, M. C.; THIRÉ, R. M. S. M.; PITA, V. J. R. R.; OAK, C. W. P.; ANDRADE, C. T. Processamento de amido de milho em câmara de mistura. Food Science and Technology, v. 24, n. 2, p. 303-310, 2004.

https://doi.org/10.1590/S0101-20612004000200025

TADERA, K.; MINAMI, Y.; TAKAAMATSU, K. MATSUOKA, T. Inhibition of alpha-glucosidase and aphaamylase by flavonoids. Journal of Nutritional Science Vitaminology, v. 52, n.2, p.149-153, 2006.

https://doi.org/10.3177/jnsv.52.149

VINUTHA, B.; PRASHANTH, D.; SALMA, K.; SREEJA, S. L.; PRATITI, D.; PADMAJA, R.; RADHIKA, S.; AMIT, A.; VENKATESHWARLU, K.; DEEPAK, M. Screening of selected Indian medicinal plants for acetylcholinesterase inhibitory activity. Journal of Ethnopharmacology, v. 109, n. 3, p. 359-363, 2007. https://doi.org/10.1016/j.jep.2006.06.014

WAHYUNI, W. T.; DARUSMAN, L. K.; SURYA, N. K. Potency of Rhizopora spp. Extracts as Antioxidant and Inhibitor of Acetylcholinesterase. Procedia Chemistry, v. 16, p. 681-686, 2015.

https://doi.org/10.1016/j.proche.2015.12.009

ZAJACZ, A.; GYEMANT, G., VITTORI, N.; KANDRA, L. Aleppo tannin: structural analysis and salivary amylase inhibition. Carbohydrate Research, v. 342, n.6, p. 717, 2007.

https://doi.org/10.1016/j.carres.2006.12.016 